\title{
BLOOD REACTION AND BLOOD GASES IN PNEUMONIA
}

\author{
By A. B. HASTINGS, J. M. NEILL, H. J. MORGAN, AND C. A. L. BINGER
}

(From the Hospital of The Rockefeller Institute, New York)

(Received for publication, July 3, 1924)

Peabody in 1912 (1) published a paper on the metabolism in pneumonia, in which he reviewed the previous literature and studied among other factors the blood gases and acid-base balance. Since Peabody, a number of other investigators have studied the blood gases and the question of the existence and importance of acidosis in pneumonia. The present paper is a report of observations on these subjects, in which recently developed methods have made possible the attainment of more complete results and apparently have justified the drawing of deductions more definite in some respects than those attainable from previous data.

Peabody stated that "the high excretion of ammonia and the low excretion of sodium chloride are two of the most characteristic features of the urine during fever. The diminution of the carbon dioxide of the blood is apparently a constant accompaniment of fever." These results indicated a shift of some degree towards acidosis in the acid-base balance, but whether it was sufficient to be of clinical significance was at the time uncertain. Peabody states, "The evidence points against the theory that the retention of sodium chloride in fever depends on acidosis. . . . . In diabetic acidosis and in experimental poisoning by mineral acids there is not a retention of bases as there is in pneumonia." In the gases of the venous blood much greater variations in oxygen than in carbon dioxide were found.

Palmer (2) found that, although considerable amounts of a very weak unknown organic acid could be titrated in the urine in certain severe cases of pneumonia, the alkali reserve of the venous blood plasma, as determined by the $\mathrm{CO}_{2}$ capacity method of Van Slyke and Cullen (3) was uniformly normal or nearly so. Acidosis of metabolic origin was consequently excluded.

Stillman, Van Slyke, Cullen, and Fitz, (4), in a series of acidosis cases of which the rest were diabetic, published protocols on one case with a greatly diminished plasma $\mathrm{CO}_{2}$ capacity in acute nephritis after pneumonia. The alkali deficit, which was accompanied by an almost complete cessation of ammonia excretion (unpublished data) was apparently due to the pneumonic nephritis. It disappeared as the kidney function and ammonia excretion improved. 
Stadie (5) and Stadie and Van Slyke (6) studied the oxygen content and capacity of the blood and the carbon dioxide content and capacity of the plasma in both venous and arterial blood of pneumonia patients. They confirmed Palmer's observation of normal alkali reserve as indicated by the $\mathrm{CO}_{2}$ capacities. From the gas contents of the blood they observed that "even when pulmonary conditions in pneumonia become so involved that the arterial blood is incompletely oxygenated, the arterial and venous carbon dioxide values are not increased above the usual normal levels." There was no evidence of pulmonary $\mathrm{CO}_{2}$ retention.

The data up to this point (1920) indicate that an acidosis of metabolic origin, such as would result in an alkali deficit in the body, is a rarity in pneumonia. Because the data do not include either determinations of the $\mathrm{CO}_{2}$ tension in the blood, or of the $\mathrm{pH}$ from which the $\mathrm{CO}_{2}$ tensions can be estimated, they do not exclude the possibility of a $\mathrm{CO}_{2}$ acidosis, due to hindrance in the evolution of $\mathrm{CO}_{2}$ from the pathologically involved lungs) although the combined determinations of $\mathrm{CO}_{2}$ content and $\mathrm{CO}_{2}$ capacity by Stadie and Van Slyke made a $\mathrm{CO}_{2}$ retention appear improbable.

Barach, Means and Woodwell (7) in 1922 estimated the $\mathrm{pH}$ of the arterial and venous blood in pneumonia by interpolation on the $\mathrm{CO}_{2}$ absorption curve, corrected for the observed oxygen unsaturation. They found the alkali reserve normal or slightly subnormal. In 3 of 10 patients, however, a low $\mathrm{pH}$ was observed which rose to normal after the crisis, the alkali reserve showing appreciable rise at the same time, although it had not been seriously lowered. The results indicated the possibility of a tendency towards both alkali deficit and lowered $\mathrm{pH}$ in some cases, and the authors suggested the use of alkali therapy in such cases.

Binger, Hastings and Neill (8), however, found that the continued use of even moderate amounts of bicarbonate in a case of pneumonia with somewhat diminished salt excreting power led to a dangerous alkalosis and edema, due to apparent inability to excrete the alkali.

It seemed advisable to make further observations on the blood changes in pneumonia patients, the more so because at the time of the work of Barach, Means and Woodwell, the colorimetric $\mathrm{pH}$ method for blood was not available, and their $\mathrm{pH}$ values were determined by a method which makes such demands on technique that a certain proportion of irregular results is difficult to avoid. Thirty observations of the $\mathrm{pH}$ and $\mathrm{CO}_{2}$ content, and 22 observations of the oxygen content and oxygen capacity of the arterial blood have accordingly been made on 16 patients. 
In our observations the gases were determined on the Van Slyke (9) nometric apparatus. The $\mathrm{pH}$ 's were determined colorimetrically by Cullen's method (10), in all cases, electrometrically in 12 cases, and by calculation from the $\mathrm{CO}_{2}$ absorption curves in 2 cases. All precautions to collect and preserve the blood without change in its constituents were observed (Austin, Cullen, et al., 11).

\section{THE $\mathrm{PH}$ DETERMTNATIONS}

Electrometric and colorimetric values.-In table 1 are given the results of the colorimetric determinations of $\mathrm{pH}$ at $20^{\circ} \mathrm{C}$. and the TABLE 1

The difference between the electrometric $p H$ at $38^{\circ}$ and the colorimetric $p H$ at $20^{\circ}$ of the arterial blood of preumonia patients

\begin{tabular}{c|c|c|c||c|c|c|c}
\hline \multirow{2}{*}{ No. } & \multicolumn{2}{|c|}{$\mathrm{pH}$} & \multirow{2}{*}{$\Delta \mathrm{pH}$} & No. & \multicolumn{2}{|c|}{$\mathrm{pH}$} & \multirow{2}{*}{$\Delta \mathrm{pH}$} \\
\cline { 2 - 3 } & Col. $20^{\circ}$ & Elect. $38^{\circ}$ & & & Col. $20^{\circ}$ & Elec. $38^{\circ}$ & \\
\cline { 1 - 3 } 19 & 7.72 & 7.42 & 0.30 & 25 & 7.77 & 7.48 & 0.29 \\
20 & 7.72 & 7.42 & 0.30 & 26 & 7.72 & 7.43 & 0.29 \\
21 & 7.71 & 7.49 & 0.22 & 27 & 7.70 & 7.43 & 0.27 \\
22 & 7.63 & 7.40 & 0.23 & 28 & 7.76 & 7.46 & 0.30 \\
23 & 7.66 & 7.40 & 0.26 & 29 & 7.82 & 7.50 & 0.32 \\
24 & 7.55 & 7.32 & 0.23 & 30 & 7.59 & 7.35 & 0.24 \\
\hline
\end{tabular}

Average $\Delta \mathrm{pH}=0.27$.

Average deviation $=0.03$.

Maximum deviation $=0.05$.

electrometric determinations made on the same blood at $38^{\circ} \mathrm{C}$. The average difference, $\Delta \mathrm{pH}$, between these determinations is $0.27 \mathrm{pH}$. The difference for the blood of normal individuals was found by Cullen to be $0.22 \mathrm{pH}$. This value has been confirmed in this laboratory. The reason for the difference between the $\Delta \mathrm{pH}$ found for normals and for pneumonia patients is unknown. The formula we have used in the calculation of the blood $\mathrm{pH}$ at $38^{\circ}$ from the colorimetric $\mathrm{pH}$ at $20^{\circ}$ is

$$
\mathrm{pH}_{38^{\circ} \mathrm{C} .}=\mathrm{pH}_{20^{\circ} \mathrm{C} .}-0.27
$$

Since there were rather wide differences in the temperatures of the patients at the time the blood analyses were made, a correction was 
applied to convert the $\mathrm{pH}$ at $38^{\circ}$ to its corresponding value at the temperature of the patient. The temperature coefficient for the $\mathrm{pH}$ of blood is not well established. Direct determinations of the electrometric $\mathrm{pH}$ of serum at $38^{\circ}$ and $20^{\circ}$ have indicated that the $\Delta \mathrm{pH}$ per $1^{\circ} \mathrm{C}$. is approximately 0.01 . This value has been used to correct the $\mathrm{pH}$ to the temperature of the blood as drawn.

Recent determinations made in this laboratory indicate that by making the colorimetric $\mathrm{pH}$ determinations at the temperature of the patient, the necessity for temperature correction is avoided (Hastings and Sendroy, paper in press) but the technique for such determinations had not been developed when the present work was done.

TABLE 2

$A$ comparison of electrometric, colorimetric and calculated $p H$ 's

\begin{tabular}{|c|c|c|c|}
\hline & Electrometric pH & Colorimetric pH & Calculated $\mathrm{pH}$ \\
\hline \multicolumn{4}{|c|}{ Normals } \\
\hline $\begin{array}{l}1 \\
2\end{array}$ & $-\overline{7.39}$ & $\begin{array}{l}7.38 \\
7.41\end{array}$ & $\begin{array}{l}7.40 \\
7.38\end{array}$ \\
\hline \multicolumn{4}{|c|}{ Pneumonia patients } \\
\hline $\begin{array}{r}9 \\
10\end{array}$ & $\overline{7.42}$ & $\begin{array}{l}7.44 \\
7.47\end{array}$ & $\begin{array}{l}7.44 \\
7.47\end{array}$ \\
\hline
\end{tabular}

$p H$ values calculated from the carbon dioxide absorption curve. Since the $\mathrm{pH}$ results of Barach, Means and Woodwell (7) were all determined by calculation from the carbon dioxide content and the carbon dioxide tension, four experiments were performed in order to compare values obtained thus with those obtained by direct electrometric or colorimetric determinations.

Two of the experiments were on the venous blood of normal individuals and two were on the arterial blood of pneumonia patients. The comparisons between the $\mathrm{pH}$ values obtained by direct determination and by calculation are given in table 2 . The agreement is within the limits of error of the method employed. Since difficulty has been experienced in obtaining satisfactory agreement by these two methods, certain points which contributed to the success of our experiments may be mentioned. 


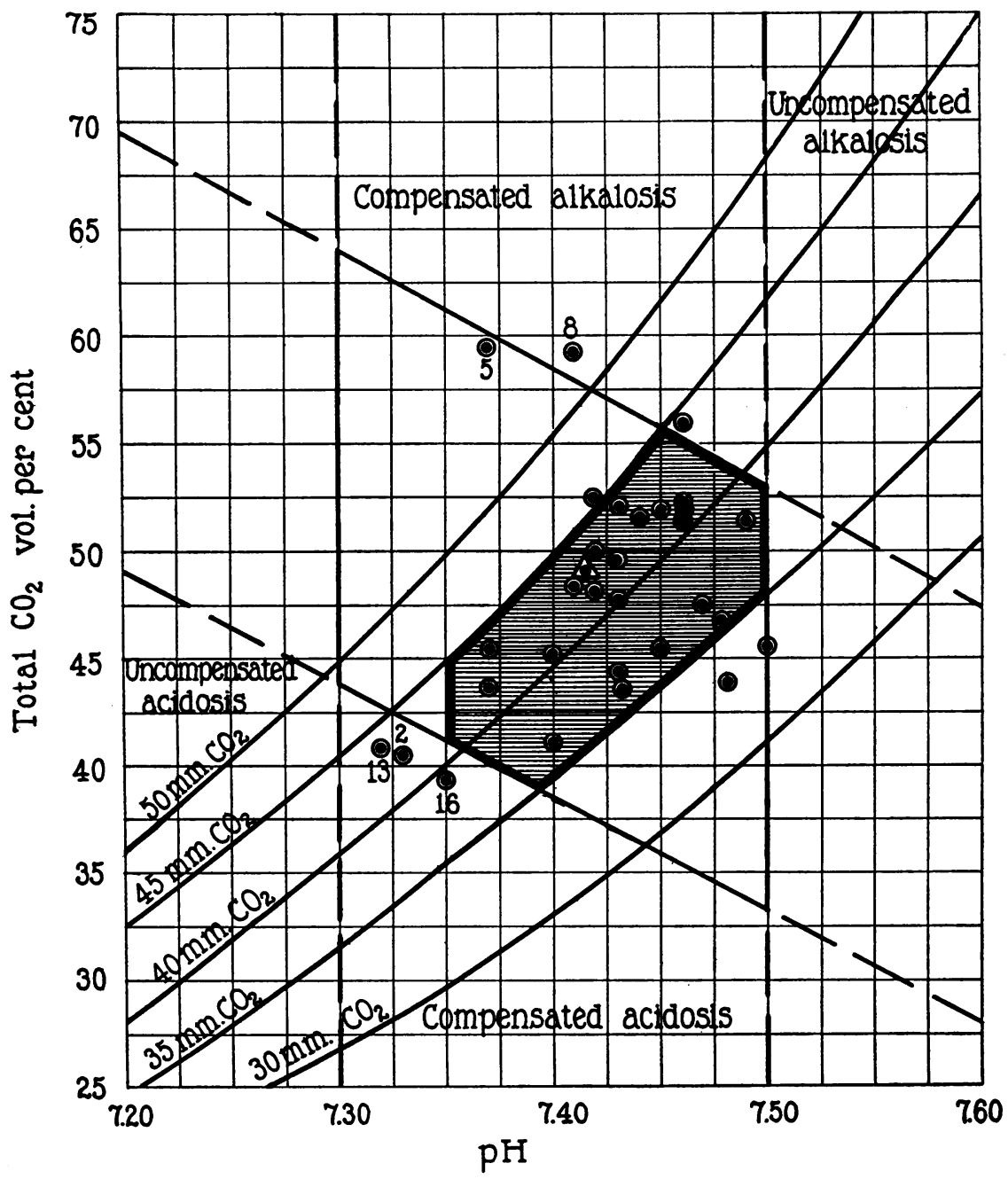

Fig. 1. Acid-base Determmations on Pneumonia Patients are Plotted with pH as Abscissae and $\mathrm{CO}_{2}$ Content as Ordinates

Constant $\mathrm{CO}_{2}$ tension lines run diagonally across the chart. The shaded area represents the revised normal acid-base area of arterial blood. The point $\Delta$ is the average of a number of normal arterial acid-base values obtained by Barr and his collaborators. 
TABL

A summary of the hydrogen ion concentrations and

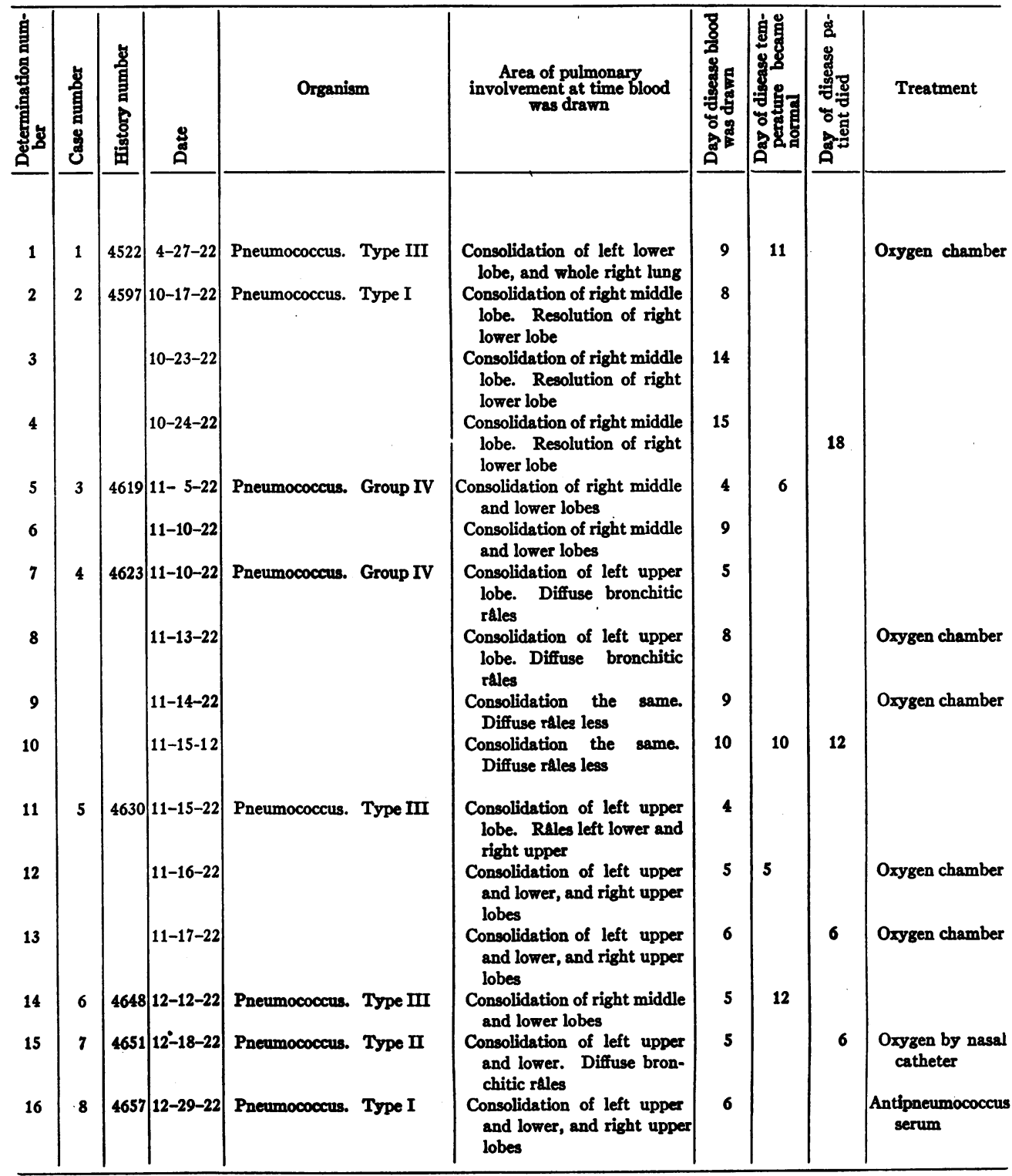




\section{E 3}

gas analyses of the arterial blood in pneumonia

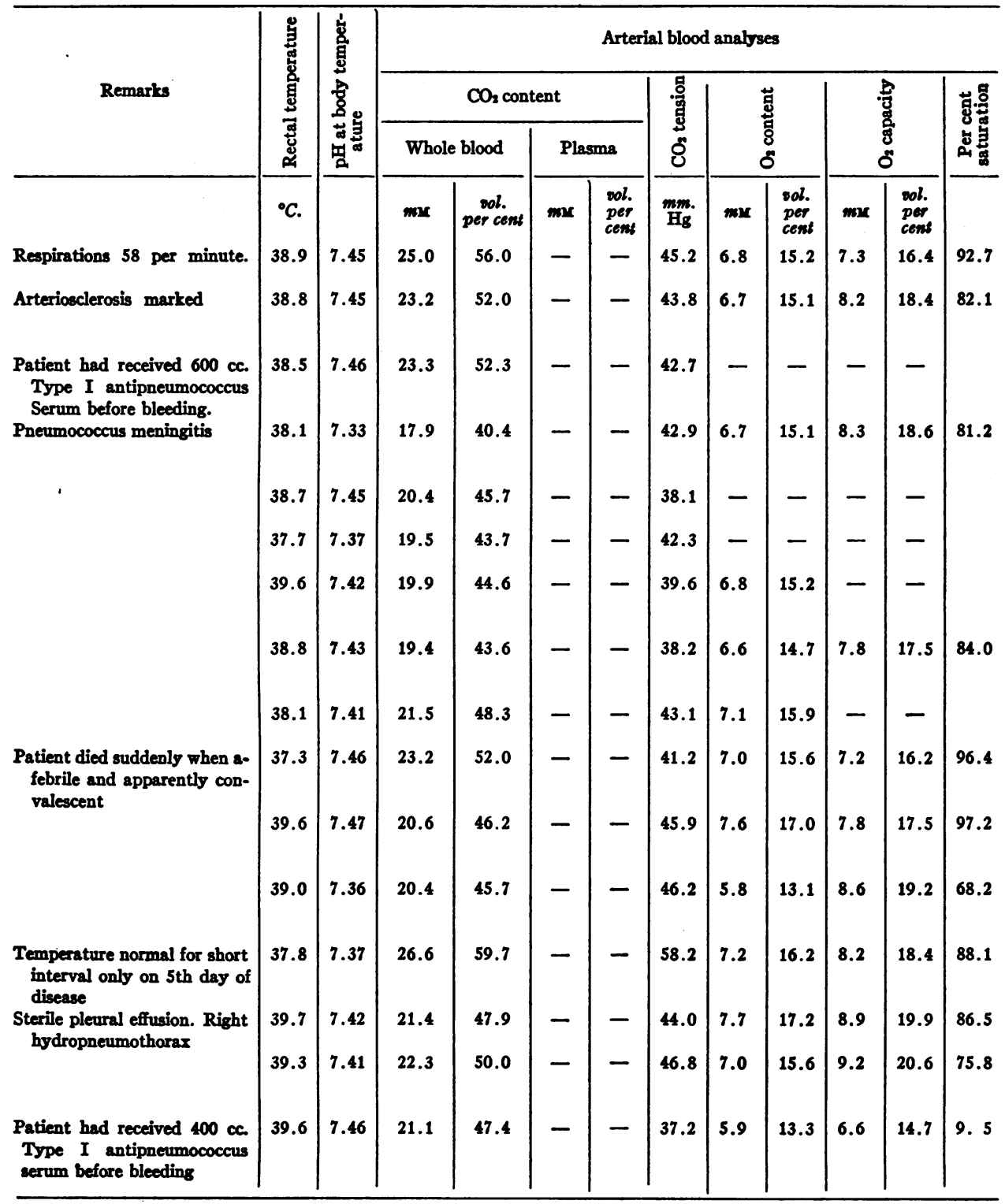


The blood was treated with one per cent neutral sodium fluoride as well as potassium oxalate which, as Lovatt Evans (12) has shown, inhibits acid formation during the period of saturation. Further,

TABLE 3

\begin{tabular}{|c|c|c|c|c|c|c|c|c|c|}
\hline 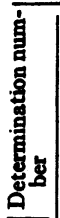 & $\begin{array}{l}\text { 岁 } \\
\text { 自 } \\
\text { 岁 }\end{array}$ & 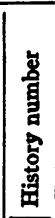 & $\stackrel{\$}{\sharp ّ}$ & Organism & $\begin{array}{l}\text { Area of pulmonary } \\
\text { involvement at time blood } \\
\text { was drawn }\end{array}$ & 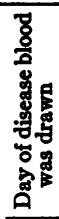 & 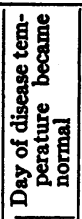 & 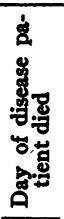 & Treatment \\
\hline 17 & & & $12-30-22$ & & $\begin{array}{l}\text { Consolidation of left upper } \\
\text { and lower, and right upper } \\
\text { lobes }\end{array}$ & 7 & 12 & & $\begin{array}{l}\text { Serum. Oxygen by } \\
\text { nasal catheter }\end{array}$ \\
\hline 18 & 9 & 4671 & $1-19-23$ & Pneumococcus. Group IV & $\begin{array}{l}\text { Consolidation of right middle } \\
\text { and lower lobes }\end{array}$ & 5 & 6 & & \\
\hline 19 & & & $1-23-23$ & & $\begin{array}{l}\text { Consolidation of right middle } \\
\text { and lower lobes }\end{array}$ & 7 & 6 & & \\
\hline 20 & 10 & 4670 & $1-20-23$ & Pneumococcus. Group IV & $\begin{array}{l}\text { Consolidation of right upper } \\
\text { lobe }\end{array}$ & 4 & 6 & & \\
\hline 21 & 11 & 4691 & $2-7-23$ & $\begin{array}{l}\text { Pneumoccus. Group IV. } \\
\text { Streptococcus hemo- } \\
\text { lyticus }\end{array}$ & $\begin{array}{l}\text { Consolidation right lower } \\
\text { lobe. Right pleural effu- } \\
\text { sion. Rales over left lower } \\
\text { lobe }\end{array}$ & 9 & & 26 & \\
\hline 22 & 12 & 4690 & $2-7-23$ & Pneumococcus. Group IV & $\begin{array}{l}\text { Consolidation of right lower } \\
\text { lobe }\end{array}$ & 5 & 6 & & \\
\hline 23 & 13 & 4708 & 3- 1-23 & Pneumococcus. Type II & $\begin{array}{l}\text { Consolidation of left lower } \\
\text { lobe }\end{array}$ & 7 & 11 & & \\
\hline 24 & & & $3-6-23$ & & $\begin{array}{l}\text { Consolidation of left lower } \\
\text { lobe }\end{array}$ & 12 & & & \\
\hline 25 & 14 & 4710 & $3-2-23$ & Pneumococcus. Group IV & $\begin{array}{l}\text { Consolidation of right middle } \\
\text { and lower lobes }\end{array}$ & 4 & 8 & & $\because$ \\
\hline 26 & & & $3-7-23$ & & $\begin{array}{l}\text { Signs of resolution over en- } \\
\text { tire right lung }\end{array}$ & 9 & & & \\
\hline 27 & 15 & 4715 & $3-6-23$ & Pneumococcus. Group IV. & $\begin{array}{l}\text { Consolidation of right middle } \\
\text { and lower lobes }\end{array}$ & 3 & 9 & & \\
\hline 28 & & & & & $\begin{array}{l}\text { Consolidation of right middle } \\
\text { and lower lobes }\end{array}$ & 4 & & & \\
\hline 29 & & & $3-14-23$ & & $\begin{array}{l}\text { Resolution of right middle } \\
\text { and lower lobes }\end{array}$ & 11 & & & \\
\hline 30 & 16 & 4729 & $3-27-23$ & Pneumococcus. Group IV & $\begin{array}{l}\text { Consolidation of whole right } \\
\text { lung and left lower lobe. } \\
\text { Diffuse bronchitic rales. }\end{array}$ & 7 & & 7 & $\begin{array}{l}\text { Oxygen by nasa } \\
\text { catheter }\end{array}$ \\
\hline
\end{tabular}

eindicates electrometric determination.

the $\mathrm{CO}_{2}$ saturation curves were determined on both the reduced and oxygenated blood, thereby permitting the proper correction to be made for the unsaturation of the blood. Finally, the $\mathrm{pK}^{\prime}$ used in 
calculating the $\mathrm{pH}$ values was obtained by taking into consideration the $\mathrm{pH}$, the concentration of total hemoglobin, and the degree of saturation of the blood (fig. $6 b$ of Van Slyke, Wu, McLean, 13).

\section{Continued}

\begin{tabular}{|c|c|c|c|c|c|c|c|c|c|c|c|c|}
\hline \multirow{3}{*}{ Remarks } & \multirow{3}{*}{ 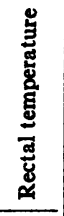 } & \multirow{3}{*}{ 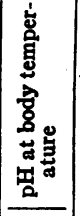 } & \multicolumn{10}{|c|}{ Arterial blood analyses } \\
\hline & & & \multicolumn{4}{|c|}{$\mathrm{CO}_{2}$ content } & \multirow{2}{*}{ 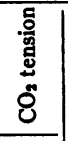 } & \multirow{2}{*}{\multicolumn{2}{|c|}{ 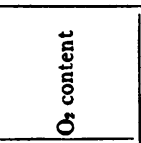 }} & \multirow{2}{*}{\multicolumn{2}{|c|}{ 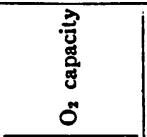 }} & \multirow{2}{*}{ 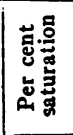 } \\
\hline & & & \multicolumn{2}{|c|}{ Whole blood } & \multicolumn{2}{|c|}{ Plasma } & & & & & & \\
\hline & ${ }^{\circ} \mathrm{C}$. & & $m \mathbf{m}$ & porc. & $m x$ & $\begin{array}{l}\text { ool. } \\
\text { per } \\
\text { cent }\end{array}$ & $\underset{\mathrm{Hg}}{\mathrm{mm}}$ & $m \mathbf{x}$ & $\begin{array}{l}\text { ool. } \\
\text { per } \\
\text { cent }\end{array}$ & $m \mathbf{m}$ & $\begin{array}{l}\text { ool. } \\
\text { per } \\
\text { cent }\end{array}$ & \\
\hline $\begin{array}{l}\text { Oxygen discontinued during } \\
\text { bleeding }\end{array}$ & 37.5 & 7.41 & 26.5 & 59.3 & - & - & 50.8 & 4.5 & 10.0 & 6.9 & 15.5 & 64.6 \\
\hline & 39.3 & 7.44 & 23.0 & 51.6 & 25.9 & 58.0 & 42.8 & 5.9 & 13.3 & 6.3 & 14.1 & 94.4 \\
\hline & 37.2 & $7.43 \epsilon$ & 23.5 & 52.8 & 27.5 & 61.7 & 45.8 & 7.1 & 15.9 & 7.3 & 16.4 & 97.0 \\
\hline & 39.1 & $7.42 \epsilon$ & 21.4 & 48.1 & 26.3 & 59.0 & 45.3 & 8.7 & 19.5 & 9.5 & 21.3 & 91.6 \\
\hline $\begin{array}{l}\text { Streptococcus hemolyticus. } \\
\text { Bronchopneumonia. Septi- }\end{array}$ & 39.6 & $7.48 \epsilon$ & 23.9 & 51.4 & 27.7 & 62.0 & 53.5 & 7.7 & 17.3 & 8.6 & 19.2 & 90.2 \\
\hline & 38.2 & $7.40 €$ & 20.2 & 43.2 & 25.2 & 56.4 & 41.5 & - & - & - & - & \\
\hline & 40.2 & $7.39 \epsilon$ & 18.4 & 41.2 & 21.7 & 48.7 & 38.7 & - & - & - & - & \\
\hline & 37.2 & $7.33 \mathrm{\epsilon}$ & 18.2 & 40.8 & - & - & 40.8 & 5.1 & 11.4 & 5.7 & 12.8 & 89.7 \\
\hline $\begin{array}{l}\text { Spread to right upper lobe } \\
\text { occurred }\end{array}$ & 39.7 & $7.47 \epsilon$ & 19.5 & 43.6 & 23.4 & 52.4 & 35.3 & 7.9 & 17.7 & 8.2 & 18.4, & 96.2 \\
\hline & 37.5 & $7.43 \epsilon$ & 22.2 & 49.7 & - & - & 42.5 & 7.4 & 16.6 & 8.1 & 18.1 & 91.8 \\
\hline Urinary retention & 39.6 & $7.42 \mathrm{E}$ & 23.3 & 52.2 & - & - & 45.2 & 4.7 & 10.6 & 7.0 & 15.6 & 68.0 \\
\hline & 40.2 & $7.45 \epsilon$ & 23.2 & 52.0 & - & - & 43.2 & 5.8 & 13.0 & 7.2 & 16.1 & 80.8 \\
\hline & 37.4 & $7.51 \mathrm{e}$ & 20.4 & 45.7 & 24.5 & 55.1 & 32.6 & 6.2 & 13.8 & 7.4 & 16.5 & 83.7 \\
\hline $\begin{array}{l}\text { Complicated by marked al- } \\
\text { buminuria with urea reten- } \\
\text { tion }\end{array}$ & 40.0 & $7.34 \mathrm{\epsilon}$ & 17.5 & 39.3 & - & - & 41.8 & - & - & - & - & \\
\hline
\end{tabular}

The protocols of these experiments and the figures showing the results are given in tables 5 and 6 , and figures 3 and 4. 


\section{RESULTS}

The experimental results are collected in table 3 and are graphically shown in the acid-base diagram, figure 1.

The $p H$ of the blood. Among the 30 observations on pneumonia patients there was no $\mathrm{pH}$ lower than 7.30 or higher than 7.50. (Where both colorimetric and electrometric values were available, the latter were taken as the more accurate.) Since the $\mathrm{pH}$ limits of 7.30 and 7.50 for normals have been confirmed in this laboratory, it may be said that no pneumonia patient studied by us had a $\mathrm{pH}$ definitely outside the normal limits. Certainly there was no case of uncompensated acidosis among them.

The $\mathrm{CO}_{2}$ content of the blood. Values of the $\mathrm{CO}_{2}$ content of arterial blood of normal resting individuals have been determined by Barr (14). The average of these determinations is 22 millimols per liter (49.4 volumes per cent).

The $\mathrm{CO}_{2}$ contents of the blood of the pneumonia patients are about equally distributed on either side of the mean line. Except for three high and three low values they lie within the original limits of the normal area outlined by Van Slyke (15). Some of these cases require special mention. Of the low ones, No. 2 had a pneumococcus meningitis and died three days later; No. 16 was complicated by nephritis and died the day the observation was made; No. 13 was afebrile at the time of the analyses. Of the high points, No. 5 was moribund and died on the day of the observation; No. 8 had been having oxygen therapy by nasal catheter. The fact that this was discontinued during the bleeding may have contributed to the marked unsaturation of the blood.

It is concluded from determinations of $\mathrm{CO}_{2}$ content taken in conjunction with those of the $\mathrm{pH}$, that an acidosis, either compensated or uncompensated, is rarely, if ever, encountered in pneumonia uncomplicated by other abnormal conditions.

The $\mathrm{CO}_{2}$ tension. Twenty-five of the thirty arterial $\mathrm{CO}_{2}$ tensions, calculated from the serum $\mathrm{pH}$ and $\mathrm{CO}_{2}$ content, were within the 35 to $45 \mathrm{~mm}$. iso-pressure lines of figure 1 . The $\mathrm{CO}_{2}$ tension was calculated from the $\mathrm{CO}_{2}$ content and plasma $\mathrm{pH}$ by formula 5 in table 4 of Austin et al. (11), viz.: 


$$
p_{\mathrm{CO}_{3}}=\frac{\left[\mathrm{CO}_{2}\right]}{0.0587 \alpha_{\mathrm{CO}_{3}}\left(1+10 \mathrm{pH}-\mathrm{pK}^{\prime}\right)}
$$

$\left[\mathrm{CO}_{2}\right]=$ volume per cent total $\mathrm{CO}_{2}$ in whole blood.

$\alpha_{\mathrm{co}}=$ solubility coefficient of $\mathrm{CO}_{2}$ in whole blood.

$p K^{\prime}=p K^{\prime}$ of Hasselbalch's equation for whole blood, $\mathrm{pH}=p K^{\prime}+\log \frac{\left[\mathrm{BHCO}_{3}\right]}{\left[\mathrm{H}_{2} \mathrm{CO}_{8}\right]}$

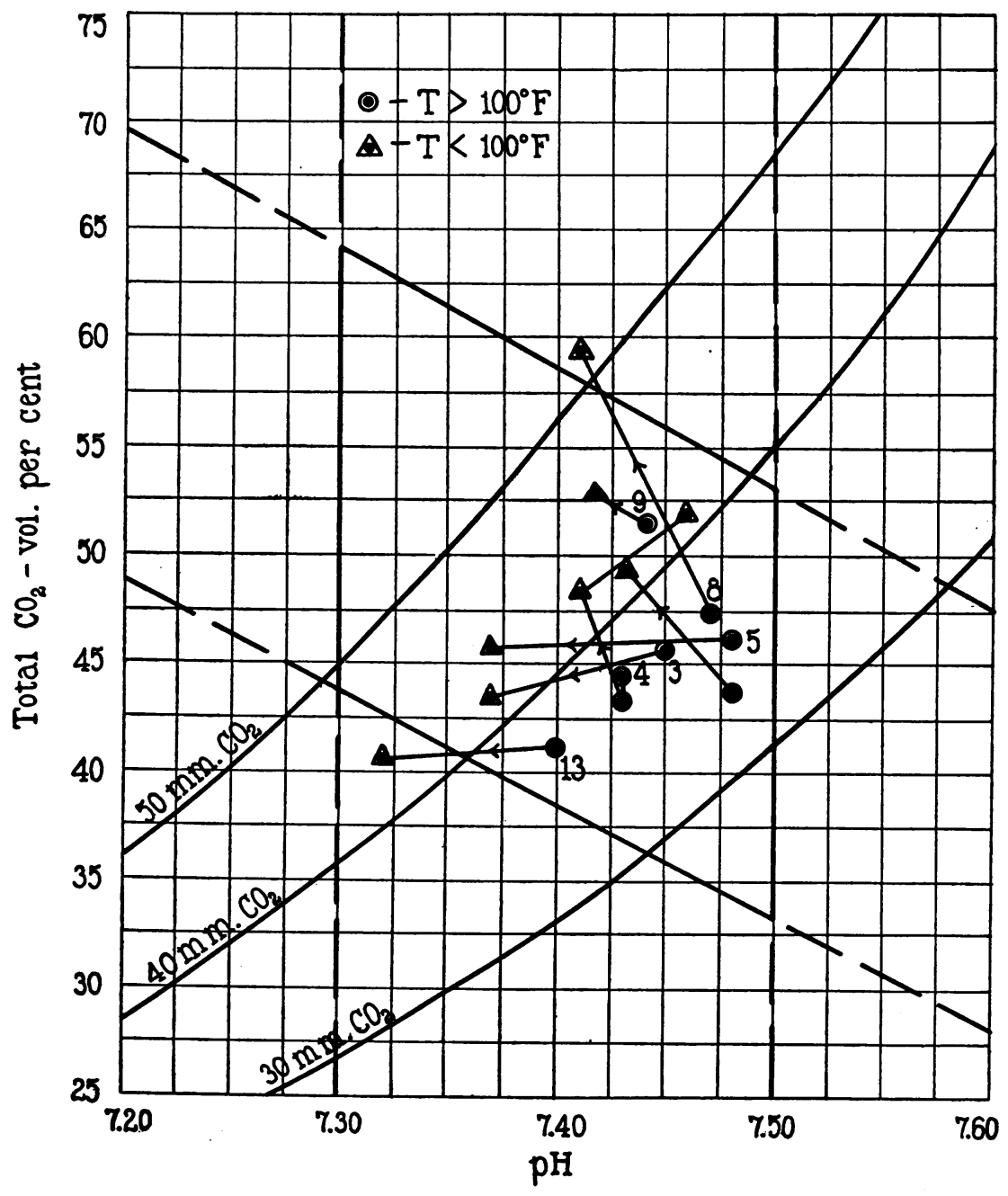

Fig. 2. Acm-base Determinations Obtanned on Pneumonta Patients Durneg and After the Febrile Period 
The value of $\alpha_{\mathrm{co}_{2}}$ was estimated to be proportional to the water content of the blood (13). The water content, for blood of varying hemoglobin content, is calculated from Equation 30 of Van Slyke, $\mathrm{Wu}$, and McLean, (13) as

cc. $\mathrm{H}_{2} \mathrm{O}$ per cc. blood $=0.94-0.0067 \mathrm{Hb}$

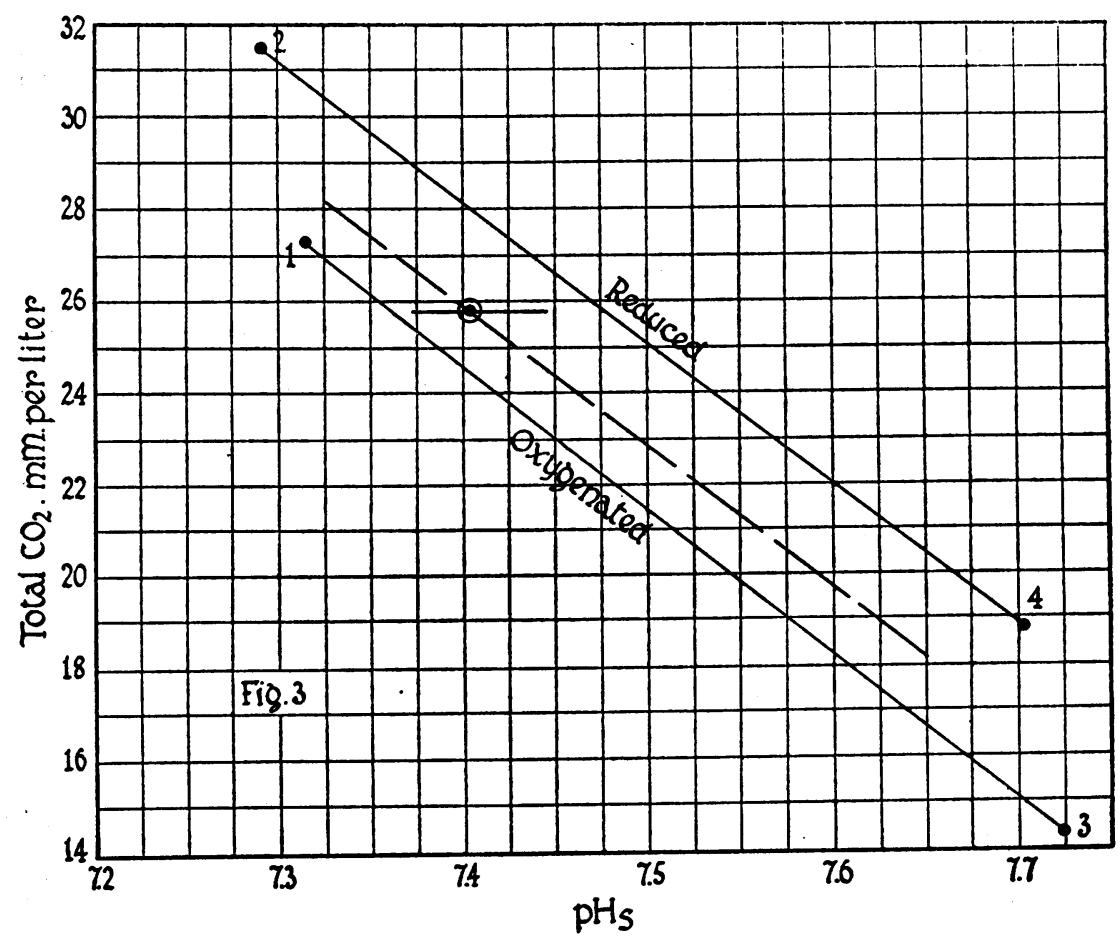

Fig. 3. Jandary 9, 1923. $\mathrm{CO}_{2}$ Absorption CuRves of Oxygenated and REduced BloOd of a Normal Individual Plotted with pH as Abscissae and $\mathrm{CO}_{2}$ Content as Ordinates

The point within the $\odot$ represents the acid-base balance of the venous blood as drawn determined by the $\mathrm{CO}_{2}$ content and degree of unsaturation. The $\mathrm{pH}$ thus estimated is 7.40; as determined colorimetrically, 7.38.

$\mathrm{Hb}=$ hemoglobin content of blood in volume per cent of oxygen capacity. (The constants in their equation are here altered to change the $\mathrm{H}_{2} \mathrm{O}$ from terms of weight to those of volume, and the $\mathrm{Hb}$ from terms of millimols to those of volumes per cent oxygen capacity.) 
Since the solubility coefficient of $\mathrm{CO}_{2}$ for water is 0.555 , the coefficient for blood is estimated as

$$
\alpha_{\mathrm{CO}_{2}}=0.555(0.94-0.0067 \mathrm{Hb})
$$

The $p K^{\prime}$ value for whole blood, as shown by Warburg (16) by Van Slyke, Wu, and McLean (13) and by Peters, Bulger, and Eisemann

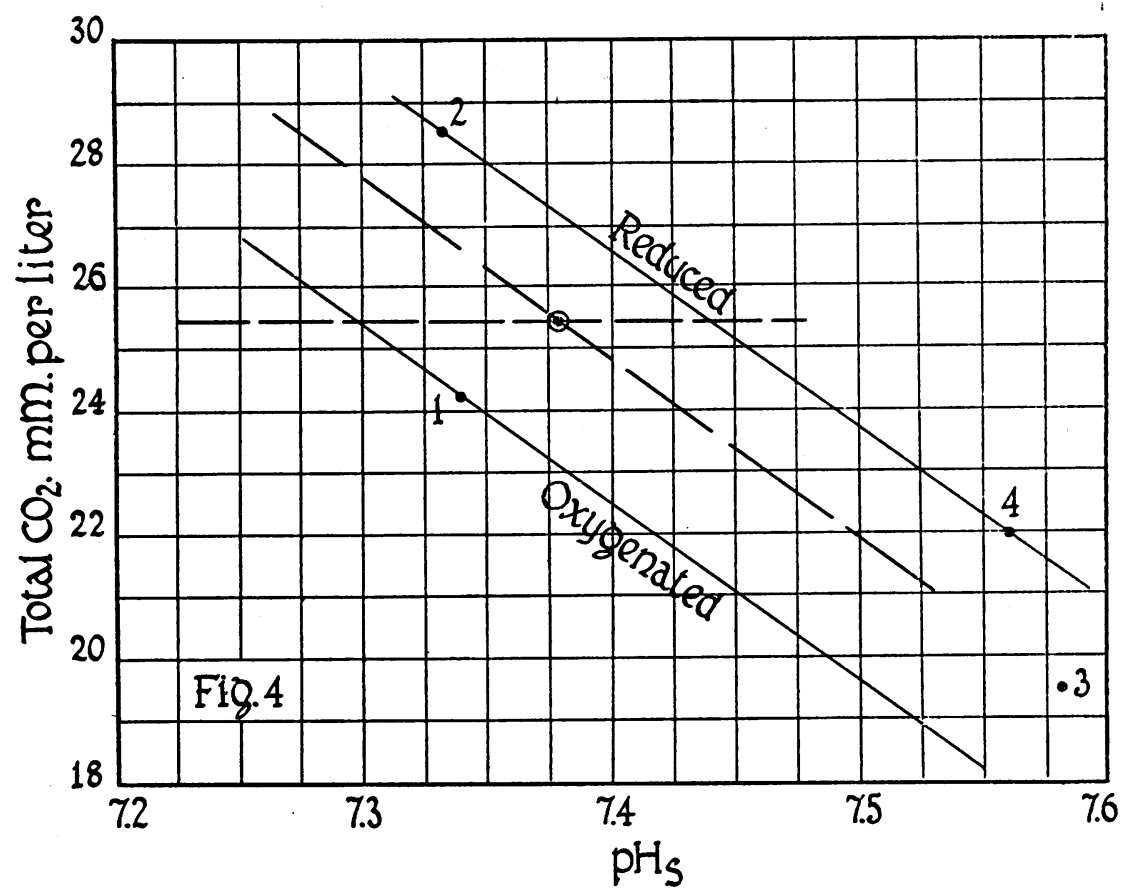

Fig. 4. January 25, $1923 . \mathrm{CO}_{2}$ Absorption Curves of Oxygenated and Reduced Blood of a Normat Indivmual Plotted with pH as Abscissae and $\mathrm{CO}_{2}$ Content as Ordinates

The point within the $\odot$ represents the acid-base balance of the venous blood as drawn determined by the $\mathrm{CO}_{2}$ content and degree of unsaturation. The $\mathrm{pH}$ thus estimated is 7.38; as determined colorimetrically 7.41; electrometrically, 7.39.

(17), is greater for whole blood than for plasma by an amount, $\Delta p K^{\prime}$, dependent on the oxygen saturation, $\mathrm{pH}$, and hemoglobin content of the blood. Hence, for whole blood,

$$
p K^{\prime}=p K^{\prime} s+\Delta p K^{\prime},
$$


where

$$
p K^{\prime}{ }_{s}=p K^{\prime} \text { for serum }=6.12
$$

$\Delta \mathrm{pK}^{\prime}$ is estimated from figure $6 b$ of Van Slyke, Wu, and McLean, with an added correction for oxygen unsaturation.

With the above values for $\alpha_{\mathrm{cos}}$ and $\mathrm{pK}^{\prime}$ in whole blood, the formula relating $p_{\mathrm{CO}_{2}}$ to $\left[\mathrm{CO}_{2}\right]$ and $\mathrm{pH}$, becomes,

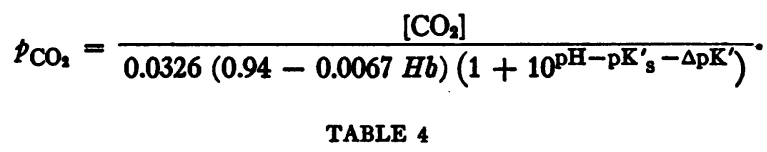

\begin{tabular}{|c|c|c|c|c|c|c|}
\hline \multirow[b]{2}{*}{ Case No. } & \multicolumn{3}{|c|}{ During febrile period } & \multicolumn{3}{|c|}{ After febrile period. } \\
\hline & $\mathrm{CO}_{2}$ tension & $\begin{array}{c}\text { Per cent } \\
\text { saturation } \\
\text { with } \\
\text { oxygen }\end{array}$ & Temperature. & $\mathrm{CO}_{2}$ tension. & $\begin{array}{c}\text { Per cent } \\
\text { saturation } \\
\text { with } \\
\text { oxygen }\end{array}$ & Temperature. \\
\hline & mm. Hg. & & ${ }^{\circ} \mathrm{C}$. & mm. Hg. & & ${ }^{\circ} \mathrm{C}$. \\
\hline 3 & 38.1 & 一 & 38.7 & 42.3 & - & 37.7 \\
\hline 4 & 39.6 & - & 39.6 & 41.2 & 96.0 & 37.3 \\
\hline & 38.2 & 84.0 & 38.8 & & & \\
\hline & 43.1 & - & 38.1 & & & \\
\hline 5 & 45.9 & 97.2 & 39.6 & 58.2 & 88.1 & 37.8 \\
\hline & 46.2 & 68.2 & 39.0 & & & \\
\hline 8 & 37.2 & 90.5 & 39.6 & 50.8 & 64.6 & 37.5 \\
\hline 9 & 42.8 & 94.4 & 39.3 & 45.8 & 97.0 & 37.2 \\
\hline 13 & 38.7 & - & 40.2 & 40.8 & 89.7 & 37.2 \\
\hline 14 & 35.3 & 96.2 & 39.7 & 42.5 & 91.8 & 37.5 \\
\hline 15 & 45.2 & 68.0 & 39.6 & 32.6 & 83.7 & 37.4 \\
\hline & 43.2 & 81.0 & 40.2 & & & \\
\hline
\end{tabular}

The $\mathrm{CO}_{2}$ tension of the arterial blood during and after the febrile period

The progress of the $\mathrm{CO}_{2}$ tension during the course of the disease is shown in eight cases in which dataduring and after the febrileperiod were obtained. These results are shown in table 4 and figure 2 . It is seen that there is a lower $\mathrm{CO}_{2}$ tension during the febrile period than after. Whether this is the result of the increased temperature alone or whether it had its origin in the local pulmonary lesion it is impossible to say. Haggard (18) found that elevation of the body temperature by immersion in hot baths was sufficient to lower the alveolar $\mathrm{CO}_{2}$ tension and reduce the dissolved $\mathrm{CO}_{2}$ in the blood; but Fridericia (19) who studied the alveolar $\mathrm{CO}_{2}$ tension in febrile diseases, believes 
that increased temperature alone is insufficient to account for the lower tension. That anoxemia per se is not the causal agent in the lowered arterial $\mathrm{CO}_{2}$ tension is suggested by the fact that the unsaturation of the arterial blood in some cases did not seem to be less in the period of low tension than in the subsequent afebrile period.

That the respiratory mechanism is unimpaired in its ability to maintain a normal $\mathrm{CO}_{2}$ tension and blood reaction is evidenced by the fact

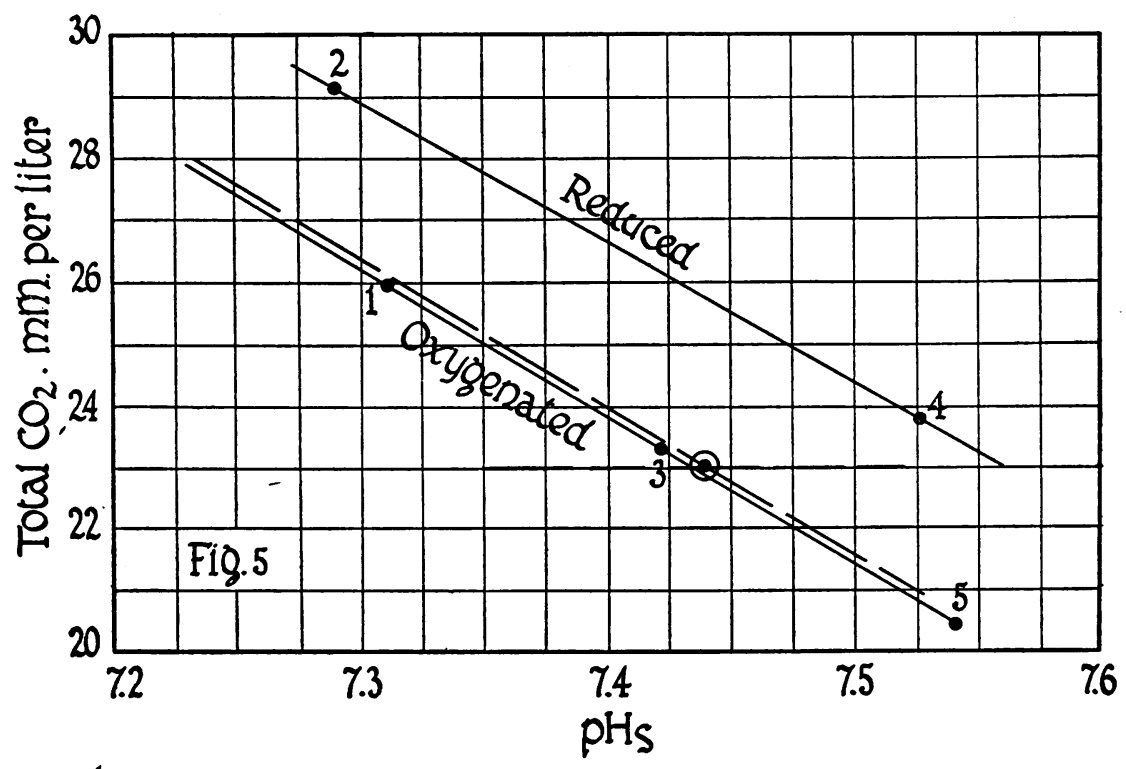

Fig. 5. January 19, 1923. $\mathrm{CO}_{2}$ Absorption Curves of Oxygenated and Reduced Blood of a Pneumonia Patient Plotted with pH as Abscissae and $\mathrm{CO}_{2}$ Content as Ordinates

The point within the $\odot$ represents the acid-base balance of the arterial blood as drawn determined by the $\mathrm{CO}_{2}$ content and degree of unsaturation. The $\mathrm{pH}$ thus estimated is 7.44; as determined colorimetrically, 7.44.

that in only 2 of the 30 analyses was the arterial $\mathrm{CO}_{2}$ tension found above $45 \mathrm{~mm}$., and in no case was the $\mathrm{pH}$ below 7.30. There was no tendency towards $\mathrm{CO}_{2}$ acidosis.

The effect of the lung changes in pneumonia on the oxygenation of the arterial blood on the other hand is significant. Of the 10 cases in which the oxygen saturation of the arterial blood was determined, 
8 showed on one or more occasions arterial saturation below 90 per cent, which figure is probably lower than occurs in any normal person at rest at sea level. In 6 cases arterial saturation below 85 per cent was noted, a level of arterial saturation at which symptoms of mountain sickness may begin in normal individuals who are transferred to high altitudes (20).

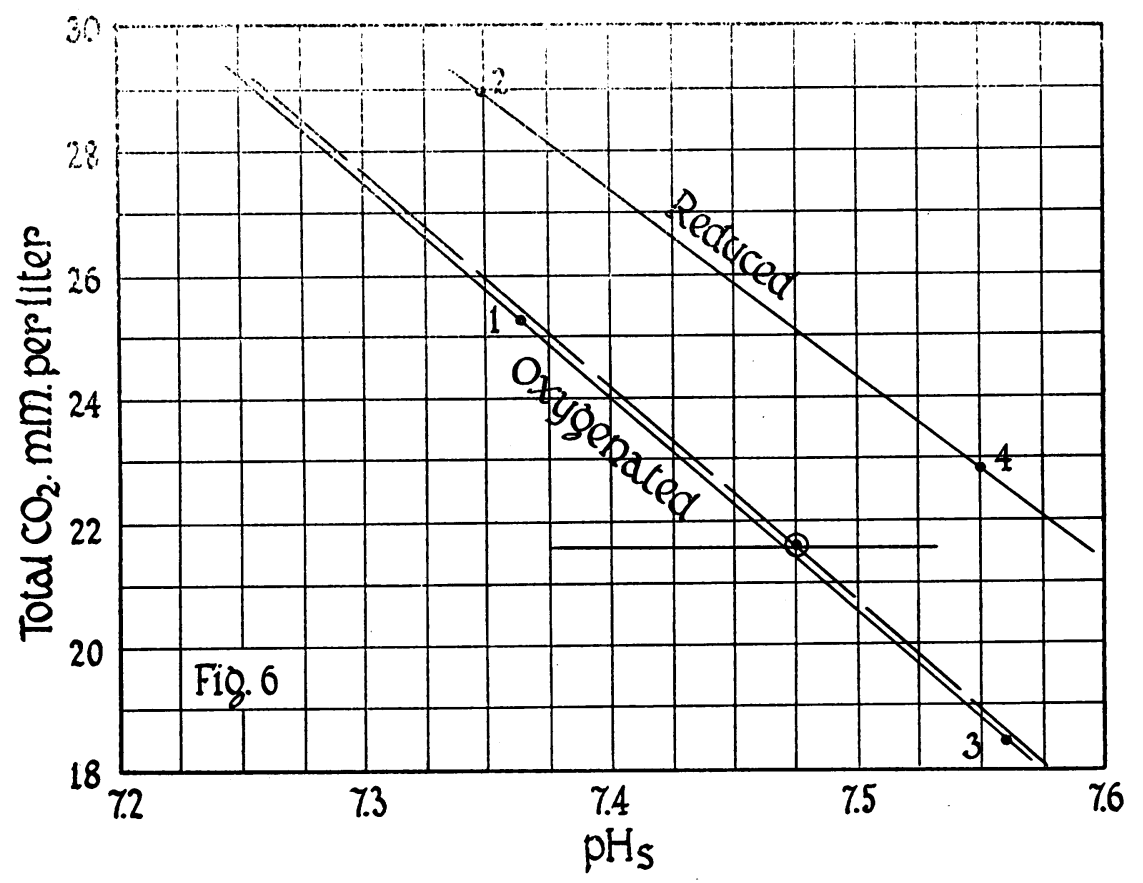

Fig. 6. Jandary 20, 1923. $\mathrm{CO}_{2}$ Absorption CuRves of Oxygenated aNd Reduced Blood of a Pneumonia Patient, Plotted with pH as Abscissae and $\mathrm{CO}_{2}$ Content as Ordińates

The point within the $\odot$ represents the acid-base balance of the arterial blood as drawn, determined by the $\mathrm{CO}_{2}$ content and degree of unsaturation. The $\mathrm{pH}$ thus estimated is 7.47; as determined colorimetrically, 7.47; electrometrically, 7.42 .

Various known facts indicate that the oxygenation of the blood in the lungs is much more susceptible to failure than is the removal of $\mathrm{CO}_{2}$. Krogh (21) has shown that $\mathrm{CO}_{2}$ diffuses through animal membranes 30 times faster than $\mathrm{O}_{2}$. Henderson (22) has calculated that 


\section{TABLE 5}

$A$ comparison of the $p H$ of normal human blood determined directly and calculated from the $\mathrm{CO}_{2}$ saturation curves. Blood treated with 0.4 per cent $\mathrm{K}_{2} \mathrm{C}_{2} \mathrm{O}_{4}+$

0.1 per cent $\mathrm{NaF}$

Normal, No. 1.

Date: January 9, 1924.

$\mathrm{pK}^{\prime}=6.12+\Delta \mathrm{pK}^{\prime}$

$\mathrm{H}_{2} \mathrm{CO}_{3}=0.0271 \mathrm{pCO}_{2}$

\begin{tabular}{|c|c|c|c|c|c|c|c|c|c|}
\hline \multicolumn{10}{|c|}{ Analysis of blood after saturation with definite $\mathrm{CO}_{2}$ and $\mathrm{O}_{2}$ tensions. } \\
\hline No. & $\mathrm{pO}_{2}$ & $\mathrm{HbO}_{2}$ & $\mathrm{pCO}_{2}$ & $\mathrm{H}_{2} \mathrm{CO}_{2}$ & $\begin{array}{c}\text { Total } \\
\mathrm{CO}_{2}\end{array}$ & $\mathrm{BHCO}_{3}$ & $\left|\log \frac{\mathrm{BHCO}_{2}}{\overline{\mathrm{H}}_{2} \mathrm{CO}_{3}}\right|$ & $\mathrm{pK}^{\prime}$ & $\mathrm{pH}$ \\
\hline & $m m$ & mx. & $m m$. & $m \mathbf{m}$. & mx. & max. & & & \\
\hline 1 & (135) & 9.18 & 66.1 & 1.79 & 27.28 & 25.49 & 1.154 & 6.165 & 7.319 \\
\hline 2 & $(0)$ & 0.11 & 79.5 & 2.15 & 31.50 & 29.35 & 1.135 & 6.154 & 7.289 \\
\hline 3 & (135) & 9.23 & 15.0 & 0.41 & 14.53 & 14.12 & 1.537 & 6.190 & 7.727 \\
\hline 4 & $(0)$ & 0.15 & 20.0 & 0.54 & 18.88 & 18.34 & 1.531 & 6.173 & 7.704 \\
\hline \multicolumn{10}{|c|}{ Analysis of blood as drawn } \\
\hline \multicolumn{2}{|c|}{$\begin{array}{c}\text { Total } \\
\mathrm{Hb}+\mathrm{HbO}_{2}\end{array}$} & \multicolumn{2}{|c|}{$\mathrm{HbO}_{2}$} & $\frac{\mathrm{HbO}_{2}}{\mathrm{Hb}+\mathrm{Hb}}$ & \multicolumn{2}{|r|}{ Total $\mathrm{CO}_{2}$} & \multicolumn{3}{|c|}{$\mathrm{pH}$} \\
\hline \multirow{2}{*}{\multicolumn{2}{|c|}{$\begin{array}{l}m \mathbf{m} . \\
(9.40)\end{array}$}} & \multirow{2}{*}{\multicolumn{2}{|c|}{$\begin{array}{l}m \mathrm{~m} . \\
5.97\end{array}$}} & per cent & & \multirow{2}{*}{$\begin{array}{l}m \mathbf{m} . \\
25.76\end{array}$} & \multirow{2}{*}{\multicolumn{3}{|c|}{$\begin{array}{l}7.40 \text {-calculated } \\
7.38 \text {-colorimetric }\end{array}$}} \\
\hline & & & & 63.0 & & & & & \\
\hline
\end{tabular}

Normal, No. 2.

Date: January 25, 1923.

$\mathrm{pK}^{\prime}=6.12+\Delta \mathrm{pK}^{\prime}$

$\mathrm{H}_{2} \mathrm{CO}_{3}=0.0270 \mathrm{pCO}_{2}$

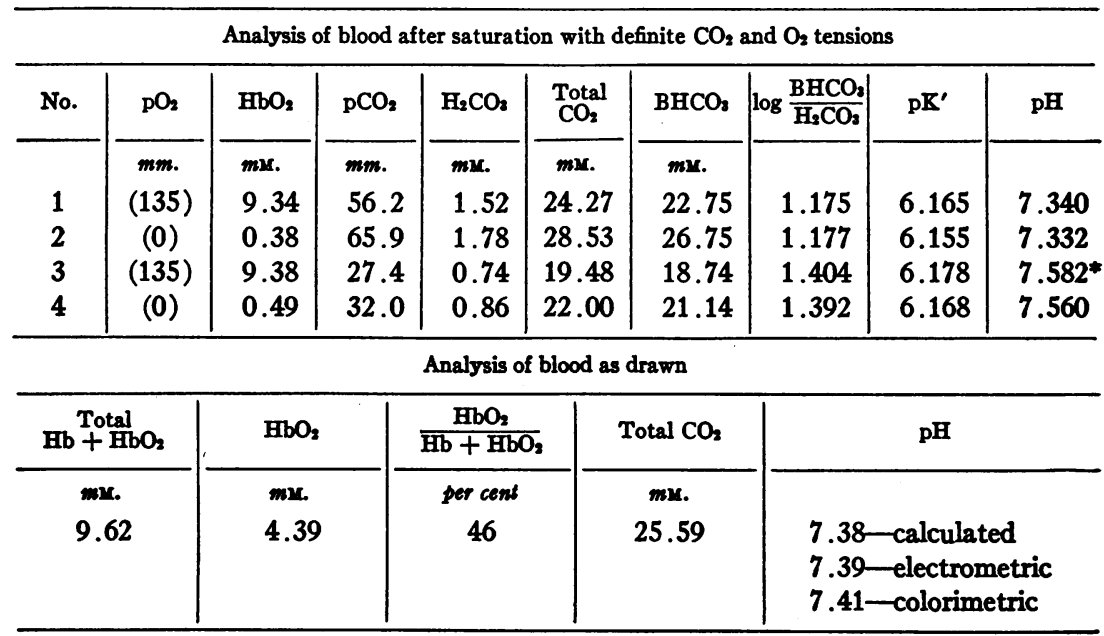

* Not used in plotting oxygenated curve. 
TABLE 6

A comparison of the $p H$ of preumonia patients' blood determined directly and calculated from the $\mathrm{CO}_{2}$ titration curves

Patient, No. 9.

Date: January 19, 1923.

$\mathrm{pK}^{\prime}=6.12+\Delta \mathrm{pK}^{\prime}$

$\mathrm{H}_{2} \mathrm{CO}_{3}=0.0280 \mathrm{pCO}_{2}$

\begin{tabular}{|c|c|c|c|c|c|c|c|c|c|}
\hline \multicolumn{10}{|c|}{ Analysis of blood after saturation with definite $\mathrm{CO}_{2}$ and $\mathrm{O}_{2}$ tensions } \\
\hline \multirow[t]{2}{*}{ No. } & $\mathrm{pO}_{2}$ & $\mathrm{HbO}_{2}$ & $\mathrm{pCO}_{2}$ & $\mathrm{H}_{2} \mathrm{CO}_{3}$ & $\begin{array}{l}\text { Total } \\
\mathrm{CO}_{2}\end{array}$ & $\mathrm{BHCO}_{2}$ & $\log \frac{\mathrm{BHCO}_{3}}{\mathrm{H}_{2} \mathrm{CO}_{3}}$ & $\mathrm{pK}^{\prime}$ & $\mathrm{pH}$ \\
\hline & $m m$. & mx. & mm. & mx. & mu. & mx. & & & \\
\hline 1 & (135) & 6.60 & 57.8 & 1.62 & 25.88 & 24.26 & 1.175 & 6.147 & 7.312 \\
\hline 2 & $(0)$ & 0.57 & 68.5 & 1.92 & 29.17 & 27.25 & 1.152 & 6.141 & 7.293 \\
\hline 3 & (135) & 6.87 & 42.1 & 1.18 & 23.27 & 22.09 & 1.272 & 6.150 & 7.422 \\
\hline 4 & (0) & 0.45 & 33.9 & 0.95 & 23.76 & 22.81 & 1.380 & 6.146 & 7.526 \\
\hline 5 & (135) & 6.73 & 28.6 & 0.80 & 20.32 & 19.52 & 1.388 & 6.156 & 7.544 \\
\hline \multicolumn{10}{|c|}{ Analysis of blood as drawn } \\
\hline \multicolumn{2}{|c|}{$\begin{array}{c}\text { Total } \\
\mathrm{Hb}+\mathrm{HbO}_{2}\end{array}$} & \multicolumn{2}{|l|}{$\mathrm{HbO}_{2}$} & $\begin{array}{c}\text { Per cent } \\
\text { saturation }\end{array}$ & \multicolumn{2}{|c|}{ Total $\mathrm{CO}_{2}$} & \multicolumn{3}{|c|}{$\mathrm{pH}$} \\
\hline \multirow{2}{*}{\multicolumn{2}{|c|}{$\begin{array}{l}m \mathrm{~m} . \\
6.90\end{array}$}} & \multirow{2}{*}{\multicolumn{2}{|c|}{$\begin{array}{l}\operatorname{mx} . \\
5.92\end{array}$}} & & \multirow{2}{*}{\multicolumn{2}{|c|}{$\begin{array}{c}m \mathrm{Mr} . \\
23.02\end{array}$}} & \multirow{2}{*}{\multicolumn{3}{|c|}{$\begin{array}{l}\text { 7.44-calculated } \\
7.44 \text {-colorimetric }\end{array}$}} \\
\hline & & & & 94.4 & & & & & \\
\hline
\end{tabular}

Patient No. 10.

Date: January 20, 1923.

$\mathrm{pK}^{\prime}=6.12+\Delta \mathrm{pK}^{\prime}$

$\mathrm{H}_{2} \mathrm{CO}_{8}=0.0270 \mathrm{pCO}_{2}$

\begin{tabular}{|c|c|c|c|c|c|c|c|c|c|}
\hline \multicolumn{10}{|c|}{ Analysis of blood after saturation with definite $\mathrm{CO}_{2}$ and $\mathrm{O}_{2}$ tensions } \\
\hline \multirow[t]{2}{*}{ No. } & $\mathrm{pO}_{2}$ & $\mathrm{HbO}_{2}$ & $\mathrm{pCO}_{2}$ & $\mathrm{H}_{2} \mathrm{CO}_{3}$ & $\begin{array}{c}\text { Total } \\
\mathrm{CO}_{2}\end{array}$ & $\mathrm{BHCO}_{3}$ & $\log \frac{\mathrm{BHCO}_{3}}{\mathrm{H}_{2} \mathrm{CO}_{3}} \mid$ & $\mathrm{pK}^{\prime}$ & $\mathrm{pH}$ \\
\hline & mm. & mM. & mm. & mM. & mx. & $m \mathrm{M}$. & & & \\
\hline 1 & (135) & & $\begin{array}{l}56.8 \\
65.1\end{array}$ & $\begin{array}{r}1.53 \\
1.76\end{array}$ & 25.31 & $\begin{array}{l}23.78 \\
27.12\end{array}$ & $\begin{array}{l}1.191 \\
1.188\end{array}$ & $\begin{array}{l}6.168 \\
6.158\end{array}$ & $\begin{array}{l}7.359 \\
7.346\end{array}$ \\
\hline $\begin{array}{l}2 \\
3\end{array}$ & $\begin{array}{c}(0) \\
(135)\end{array}$ & $\begin{array}{l}0.25 \\
9.19\end{array}$ & $\begin{array}{l}65.1 \\
27.4\end{array}$ & $\begin{array}{l}1.76 \\
0.74\end{array}$ & 18.45 & $\begin{array}{l}27.12 \\
17.71\end{array}$ & $\begin{array}{l}1.188 \\
1.380\end{array}$ & $\begin{array}{l}0.150 \\
6.178\end{array}$ & $\begin{array}{l}7.040 \\
7.558\end{array}$ \\
\hline 4 & $(0)$ & 0.51 & 33.3 & 0.90 & 22.72 & 21.82 & 1.385 & 6.167 & 7.552 \\
\hline \multicolumn{10}{|c|}{ Analysis of blood as drawn } \\
\hline \multicolumn{2}{|c|}{$\begin{array}{c}\text { Total } \\
\mathrm{Hb}+\mathrm{HbO}_{2}\end{array}$} & \multicolumn{2}{|c|}{$\mathrm{HbO}_{2}$} & $\begin{array}{l}\text { Per cent } \\
\text { saturatio }\end{array}$ & \multicolumn{2}{|c|}{ Total $\mathrm{CO}_{2}$} & \multicolumn{3}{|c|}{$\mathrm{pH}$} \\
\hline & & \multicolumn{2}{|c|}{$\begin{array}{l}\text { mu. } \\
8.69\end{array}$} & 91.4 & \multicolumn{2}{|r|}{$\begin{array}{c}m \mathrm{M} . \\
21.45\end{array}$} & \multicolumn{3}{|c|}{$\begin{array}{l}\text { 7.47-calculated } \\
7.42 \text {-electrometric } \\
7.47 \text {-colorimetric }\end{array}$} \\
\hline
\end{tabular}


the blood attains practically the $\mathrm{CO}_{2}$ tension of the alveolar air by the time it has passed through about half the length of a lung capillary, while the arterial blood after traversing completely the pulmonary capillaries still has an oxygen tension about 25 millimeters lower than the alveolar air. It has furthermore been shown by various observers that the respiratory mechanism shows a relatively weak response to oxygen lack as compared with that to carbon dioxide excess. Accumulation of $\mathrm{CO}_{2}$ may cause a man to increase his ventilation per minute by 1000 per cent, while the maximum response to oxygen lack is about 50 per cent. Furthermore, if part of the lung area is cut off from air, it is possible by over ventilation of the remainder to keep the $\mathrm{CO}_{2}$ tension of the mixed arterial blood down to normal; but since only 20 volumes per cent of oxygen can be held by the average blood, it is not possible to overcharge one portion of the pulmonary blood with oxygen in order to compensate for under oxygenation in another. These considerations would lead to the conclusion that, in any individual breathing the ordinary atmosphere, respiratory hindrance must result in serious anoxemia long before $\mathrm{CO}_{2}$ acidosis has become at all significant.

It will be noted in figures 1 and 2 that the shaded area indicated as normal is bounded not only by normal $\mathrm{pH}$ and alkali reserve lines, but also by the 35 and $45 \mathrm{~mm}$. $\mathrm{CO}_{2}$ tension lines within which the alveolar tensions of most normal individuals lie. It appears from results at present available that respiration is stimulated by high $\mathrm{CO}_{2}$ tension of itself, as well as by the high $\left[\mathrm{H}^{+}\right]$it may cause, and that the condition found in the blood is a resultant of the two effects.

\section{SUMMARY}

1. A study has been made of the $\mathrm{pH}, \mathrm{CO}_{2}$ content, $\mathrm{CO}_{2}$ tension, oxygen content, and oxygen capacity of the arterial blood in pneumonia. The $\mathrm{CO}_{2}$ tension was calculated from the $\mathrm{pH}$ and $\mathrm{CO}_{2}$ content of the blood. The other values were all determined directly.

2. A comparison was made of colorimetric and electrometric $\mathrm{pH}$ values with values calculated from the $\mathrm{CO}_{2}$ absorption curves. A fair degree of consistency was obtained.

3. A lower arterial $\mathrm{CO}_{2}$ tension during the febrile period than after the return to normal temperature was noted in 7 cases. Oxygen 
unsaturation and lowered $\mathrm{CO}_{2}$ tension do not occur together with sufficient regularity to indicate a causal relationship. Such relationship between temperature and $\mathrm{CO}_{2}$ tension seems more probable.

4. No tendency towards an acidosis of either metabolic or respiratory origin was noted. The alkali reserve was within or near normal limits in every case. The $\mathrm{pH}$ likewise was in each instance within normal limits, 7.30 to 7.50 , with the greater number of observations in the more alkaline half of this range.

5. These results contra-indicated alkali therapy in all the pneumonia cases studied.

6. In 8 of the 10 cases in which the arterial oxygen saturation was determined, an abnormally low saturation was observed at some stage of the disease. Taken with the non-occurrence of $\mathrm{CO}_{2}$ acidosis, these results support the conclusion, made probable by known physiological and physico-chemical data, that when the mechanism for gas exchange in the lungs is affected absorption of oxygen fails before elimination of carbon dioxide is significantly impaired.

\section{BIBLIOGRAPHY}

1. Peabody, F. W. Jour. Exp. Med., 1912, xvi, 701.

2. Palmer, W. W. Jour. Exp. Med., 1917, xxvi, 495.

3. Van Slyke, D. D., and Cullen, G. E. Jour. Biol. Chem., 1917, xxx, 289.

4. Stillman, E., Van Slyke, D. D., Cullen, G. E., and Fitz, R. Jour. Biol. Chem., 1917, xxx, 405.

5. Stadie, W. C. Jour. Exp. Med., 1919, xxx, 215.

6. Stadie, W. C., and Van Slyke, D. D. Jour. Biol. Chem., 1920, xli, 191.

7. Barach, A. L., Means, J. H., and Woodwell, M. N. Jour. Biol. Chem., 1922, 1, 413.

8. Binger, C. A. L., Hastings, A. B., and Neill, J. M. Arch. Int. Med., 1923, $\mathrm{xxxi}, 145$.

9. Van Slyke, D. D. Proc. Nat. Acad. Sc., 1921, vii, 229.

10. Cullen, G. E. Jour. Biol. Chem., 1922, lii, 501.

11. Austin, J. H., Cullen, G. E., Hastings, A. B., McLean, F. C., Peters, J. P., and Van Slyke, D. D. Jour. Biol. Chem., 1922, liv, 121.

12. Evans, C. L. Jour. Physiol., 1922, lvi, 146.

13. Van Slyke, D.D., Wu, H., and McLean,F.C. Jour. Biol.Chem., 1923,1vi, 765.

14. Barr, D. P., Himwich, H.E., and Green, R.P. Jour. Biol. Chem., 1923, lv, 495.

15. Van Slyke, D. D. Jour. Biol. Chem., 1921, xlviii, 153.

16. Warburg, E. Biochem. J., 1922, xvi, 153. 
17. Peters, J. P., Bulger, H. A., and Eisenman, A. J. Jour. Biol. Chem., 1923, lv, 687.

18. Haggard, H. W. Jour. Biol. Chem., 1920, xliv, 131.

19. Fridericia, L. S., and Olsen, O. Deutsch. Arch. klin. Med., cvii, 236.

20. Barcroft, J., Binger, C. A., Bock, A. V., Doggart, J. H., Forbes, H. S., Harrop, G., Meakins, J. C., and Redfield, A. C. Trans. Roy. Soc. 1922, ccxi, (series B) 351 .

21. Krogh, A. The anatomy and physiology of the capillaries. New Haven, 1921.

22. Henderson, J. L., Bock, A. V., Field, H., and Stoddard, J.L. Jour. Biol. Chem. 1924, lix, 379. 